\title{
Genetic Diversity and Population Structure of Field Isolates of Ganoderma Boninense from Oil Palm Plantation in Solomon Islands ${ }^{\dagger}$
}

\author{
Agnieszka Mudge ${ }^{1, *}$, Derick Rama ${ }^{2}$, Carmel Pilotti ${ }^{3}$ and Ian Godwin ${ }^{1}$ \\ 1 The Queensland Alliance for Agriculture and Food Innovation (QAAFI), The University of Queensland, \\ St Lucia, QLD 4072, Australia; i.godwin@uq.edu.au \\ 2 Guadalcanal Plains Palm Oil Ltd. (GPPOL), Tetere, Solomon Islands; derick.rama@nbpol.com \\ 3 Papua New Guinea Oil Palm Research Association, Dami Research Station, West New Britain Province, \\ Papua New Guinea P.O. Box 97, Australia; cpilotti@global.net.pg \\ * Correspondence: a.mudge@uq.edu.au \\ + Presented at the third International Tropical Agriculture Conference (TROPAG 2019), Brisbane, Australia, \\ 11-13 November 2019.
}

Published: 16 January 2020

Oil palm (Elaeis guineensis Jacq.) is a long-term perennial crop of great economic importance to many countries in tropical Asia/Oceania, providing export revenue and much needed income to both large plantations and smallholders. Oil palm is the most efficient oil producing plant, with an annual production per hectare more than five times that of any other vegetable crop. Unfortunately basal stem rot (BSR), caused by fungus Ganoderma boninense, poses a major threat to the oil palm industry and hence to farmers' livelihoods. The only long-term control for this disease is through improving cultural practices and the use of more resistant planting material. Ganoderma causes white rot in both felled palm logs and in living palms. It has been suspected that Ganoderma found on logs is an inoculum source for infection of living palms. In this study we used $>13,000$ GBS markers, to analyse a population of 300 isolates from an oil palm plantation in Solomon Islands (SI). The isolates were collected from fruiting bodies found on felled logs (saprophytes) and on living palms (pathogens). Isolates from Australia and Papua New Guinea (PNG) were included for comparison. Phylogenetic analysis revealed that overall there is large genetic variability among the isolates, as expected of a sexually reproducing organism. The SI isolates fell into two clades. A third of the SI isolates clustered with Australian and PNG isolates, indicating some gene flow between the counties. Our results confirm the suspicion that Ganoderma on felled logs is indeed a source of inoculum for BSR infection of living palms, which in turn has implications for disease management.

(C) 2020 by the authors. Licensee MDPI, Basel, Switzerland. This article is an open access article distributed under the terms and conditions of the Creative Commons Attribution (CC BY) license (http://creativecommons.org/licenses/by/4.0/). 